\title{
Complement component C3 functions as an embryotrophic factor in early postimplantation rat embryos
}

\author{
MAKOTO USAMI*,1, KATSUYOSHI MITSUNAGA ${ }^{2}$, ATSUKO MIYAJIMA ${ }^{1}$, \\ MOMOKO SUNOUCHI ${ }^{1}$ and OSAMU DOI ${ }^{3}$ \\ ${ }^{1}$ Division of Pharmacology, National Institute of Health Sciences, Tokyo, ${ }^{2}$ School of Pharmaceutical \\ Sciences, Toho University, Chiba and ${ }^{3}$ Laboratory of Animal Reproduction, United Graduate School of \\ Agricultural Science, Gifu University, Gifu, Japan
}

\begin{abstract}
A presumed embryotrophic factor for early postimplantation rat embryos, partially purified from rat serum, was identified as complement component $\mathrm{C} 3$ (C3), the central component of the complement system, by sequence analysis of its $\mathrm{N}$-terminal. Purified rat $\mathrm{C} 3$ showed embryotrophic activity for rat embryos cultured from day 9.5 of gestation for $48 \mathrm{~h}$ in the culture medium composed of rabbit serum. The maximum embryotrophic activity of $\mathrm{C} 3$ was observed around $0.5 \mathrm{mg} / \mathrm{ml}$, a level which is lower than rat serum C3 levels. In the culture medium composed of rat serum, cultured rat embryos selectively consumed C3, and C3-depletion by cobra venom factor affected embryonic growth. Inactivation of the internal thiolester bond of $\mathrm{C} 3$, the critical functional site for its activity in the complement system, by methylamine had no effects on its embryotrophic activity. Purified rabbit C3 had only weak embryotrophic activity for cultured rat embryos, suggesting species specificity of the embryotrophic activity of $\mathrm{C} 3$. Immunochemical analyses showed the specific presence of $\mathrm{C} 3$ on the visceral yolk sac, but not on the embryo proper of day 9.5 or 10.5 rat embryos both in utero and in vitro. In analysis using fluorescein-labeled rat C3, unfragmented C3s bound to the visceral yolk sac stronger than C3b, the primary active fragment of $\mathrm{C} 3$ in the complement system. These results indicate that $\mathrm{C} 3$, which has always been considered to be detrimental to embryos, functions as an embryotrophic factor by novel mechanisms probably through the visceral yolk sac. The present study thus provides new insights into functions of $\mathrm{C} 3$ and postimplantation embryonic growth.
\end{abstract}

KEY WORDS: C3, embryotrophic factor, postimplantation growth, rat embryo, yolk sac

\section{Introduction}

In early postimplantation mammalian embryos, extensive cell proliferation and differentiation occur for the major organogenesis, and therefore it is considered that embryotrophic factors play important roles. Culture of postimplantation rodent embryos has been widely used for the investigation of embryotrophic factors since it allows the embryos to grow in rat serum as well as in the uterus (Morriss-Kay, 1993). So far, many known nutrients and growth factors in serum, such as glucose, pantothenic acid, riboflavin, inositol, folic acid, niacinamide, methionine, iron, hemoglobin, transferrin, epidermal growth factor, insulin, insulin-like growth factors, vasoactive intestinal peptide, prolactin, activitydependent neurotrophic factor, basic fibroblast growth factor, vascular endothelial growth factor, platelet-derived endothelial growth factor and platelet-derived growth factor, have been shown to have embryotrophic activity (Cockroft, 1979; Flynn et al., 1987; Klug et al., 1990; Young et al., 1997; Pratten, 1998; Travers et al., 1992; Gressens et al., 1993; Karabulut et al., 1999; Glanzer et al., 1999; Ulger et al., 2000; Price et al., 2003).

There remain, however, unidentified embryotrophic factors in serum that are difficult to investigate because cultured rodent embryos require high concentrations of serum in the culture

\footnotetext{
Abbreviations used in this paper: C3, complement component C3; CVF, cobra venom factor; FITC, fluorescein-4-isothiocyanate; HBSS, Hanks' balanced salt solution.
}

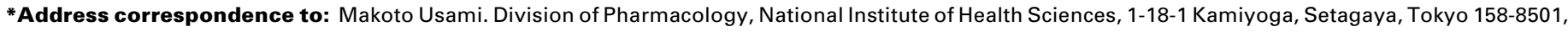
Japan. Fax: +81-3-3707-6950. e-mail: usami@nihs.go.jp
} 
medium. In a previous study, we partially purified and characterized an embryotrophic factor for early postimplantation rat embryos from rat serum (Usami and Ohno, 1996). For this purpose, rabbit serum has been used as a basal culture medium because it is non-toxic and lacks embryotrophic activity for rat embryos, which is complemented by the addition of this embryotrophic factor (Usami et al., 1992). This embryotrophic factor was an acid-labile glycoprotein with $M k 180 \times 10^{3}$, and had disulfide bonds and no affinity for heparin. By electrophoretic analysis, a protein presumed to be the embryotrophic factor was identified as a heterodimer composed of band a and b proteins, with $M k 116 \times 10^{3}$ and $62 \times 10^{3}$ respectively, linked by disulfide bonds (Usami and Ohno, 1996).

In the present study, we identified this presumed embryotrophic factor as complement component C3 (C3), the central component of the complement system (Law and Reid, 1995). We further showed that the critical functional site or primary active fragment of $\mathrm{C} 3$ in the complement system is not involved in the embryotrophic activity, and that $\mathrm{C} 3$ is present and binds on the visceral yolk sac specifically.

\section{Results}

\section{Identification of the presumed embryotrophic factor as C3}

To identify the presumed embryotrophic factor, sequences of twenty amino acids from the $\mathrm{N}$-termini of the band $a$ and $b$ proteins of the partially purified embryotrophic factor were determined by microsequencing (Fig. 1A). Homology search of a protein database indicated that these sequences matched completely with those of the $\alpha$ - and $\beta$-chains of rat C3 (Swiss-Prot accession No. P01026). Purified rat C3 had the same electrophoretic pattern as the partially purified embryotrophic factor (Fig. 1A). The biochemical characters of C3 (Daha et al., 1979; Lambris etal., 1994) are consistent with those of the embryotrophic factor described above. The presumed embryotrophic factor was thus identified as C3.

Fig. 1. Identification of the presumed embryotrophic factor as C3. (A) N-terminal amino acid sequences of the presumed embryotrophic factor with electrophoretic patterns of the partially purified embryotrophic factor and purified rat C3. The single-letter amino acid code was used. Proteins $(2 \mu \mathrm{g} / 10$ $\mu$ l) were applied on each lane and stained with Coomassie Brilliant Blue (CBB). (B) Doseresponse relationship of embryotrophic activity of $\mathrm{C} 3$ as determined by embryonic protein of rat embryos cultured from day 9.5 for $48 \mathrm{~h}$ in the culture medium composed of rabbit serum. Means of six embryos are shown. Error bars represent s.e.m. (C) Appearance of rat embryos cultured in rabbit serum with the addition of rat $\mathrm{C} 3$. The concentration of purified rat $\mathrm{C} 3$ in the culture medium was 0.65 $\mathrm{mg} / \mathrm{ml}$. cp, chorio-allantoic placenta; em, embryo proper; vy, visceral yolk sac.
Embryotrophic activity of C3 was examined by the addition of C3 purified from rat plasma to the culture medium composed of rabbit serum in the culture of day 9.5 rat embryos for $48 \mathrm{~h}$. The addition of C3 increased embryonic protein with the maximum and a plateau around $0.5 \mathrm{mg} / \mathrm{ml}$ of C3 (Fig. 1B). This concentration was comparable to the $\mathrm{C} 3$ concentration obtained by the addition of dialyzed rat serum and was therefore lower than rat serum C3 levels. The embryos also showed morphological growth by the addition of C3 (Fig. 1C).

\section{C3 and growth of rat embryos in the medium composed of rat serum}

Consumption of $\mathrm{C} 3$ in the culture medium composed of rat serum by rat embryos was determined in order to deny the possibility that rat $\mathrm{C} 3$ is required only for rat embryos cultured in rabbit serum and to confirm the embryotrophic activity of C3. To accelerate the consumption of culture medium constituents, the number of embryos per culture bottle was increased; six or nine embryos in addition to usual three embryos were cultured in a bottle containing a fixed amount $(4 \mathrm{ml})$ of rat serum as a culture medium. The concentration of $\mathrm{C} 3$ in the culture medium at the end of culture was decreased linearly with the increased embryonic protein per culture bottle at a greater rate compared to those of total protein, albumin and transferrin, indicating selective consumption of $\mathrm{C} 3$ by the embryos in accordance with their growth (Fig. 2A). Albumin and transferrin synthesis by the cultured embryos are not considered to account for these changes because at this embryonic stage albumin synthesis is not detected (Williams et al., 1986) and maternal transferrin is the primary source (Huxham and Beck, 1985). Glucose, the major energy source at this embryonic stage (Tanimura and Shepard, 1970),
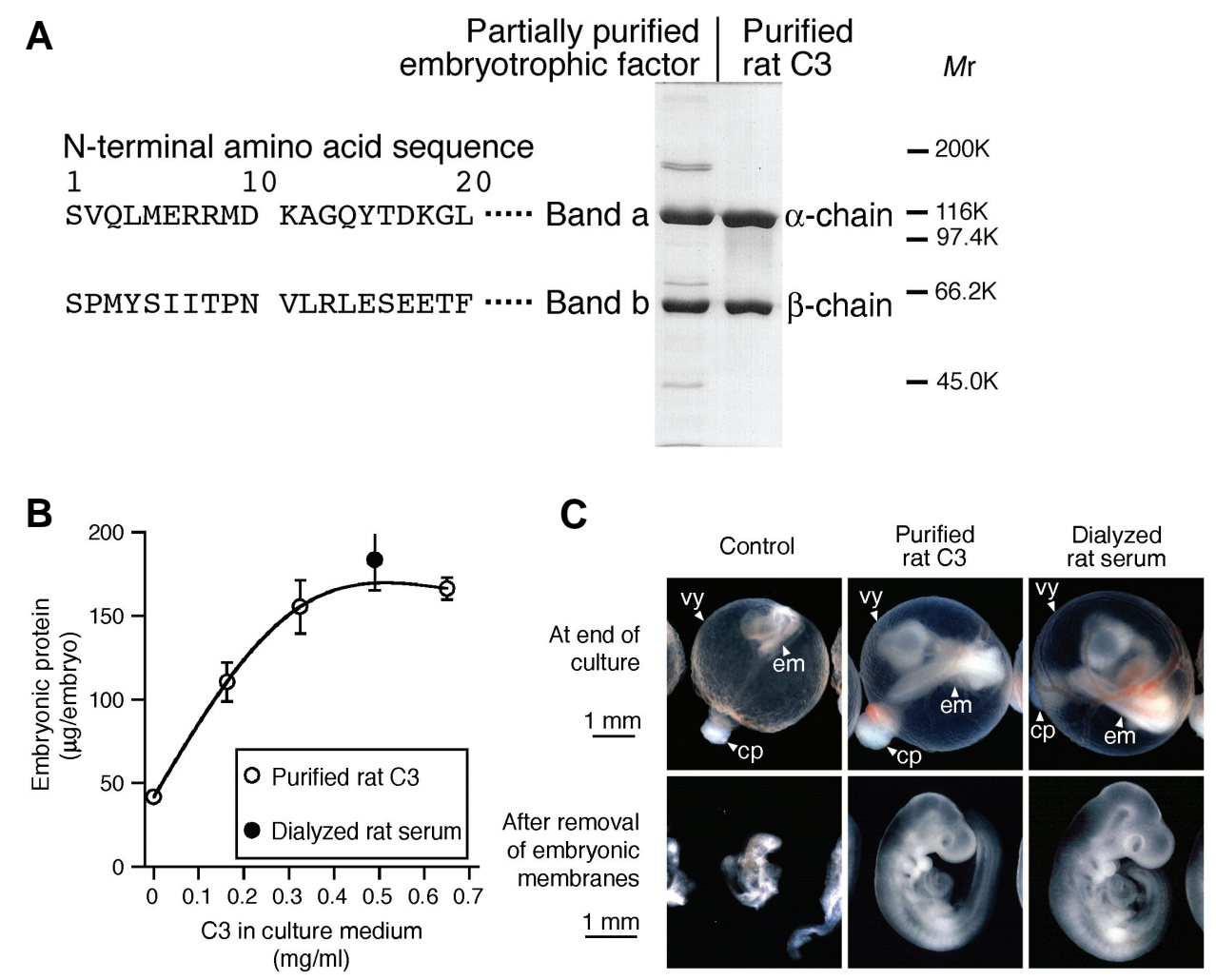
was decreased most markedly and was almost exhausted with nine embryos per bottle, suggesting that its amount was a limiting factor for embryonic growth under these culture conditions.

The embryotrophic activity of C3 was further confirmed by the culture of rat embryos in the culture medium composed of C3depleted rat serum. To deplete C3, cobra venom factor (CVF) was added to the culture medium before culture. By the addition of CVF, which specifically cleaves C3 into C3a and C3b fragments, embryonic protein was decreased, and the morphological growth of the embryo was inhibited (Fig. 2 B,C). The electrophoretic analysis of the culture medium with the addition of CVF confirmed the specific depletion of $\mathrm{C} 3$ as indicated by the disappearance of the $\mathrm{C} 3 \alpha$-chain (Fig. 2D). Unfortunately, the addition of rat C3 with CVF $(\mathrm{CVF}+\mathrm{C} 3)$ did not improve the inhibited embryonic growth (Fig. 2 B,C), probably because the additional C3 was also degraded by CVF and could not increase the amount of active C3 in the culture medium in spite of the increased C3 $\beta$-chain (Fig. 2D). It was noted that the $\alpha$-chain that should be produced by CVF from the $\alpha$-chain of C3 was not detected indicating its degradation. Although there is a possibility that CVF directly affect the embryonic growth, there were no overt effects at its lower concentrations where depletion of $\mathrm{C} 3$ in the culture medium did not occur (data not shown). It is considered from these results that $\mathrm{C} 3$ functions as an embryotrophic factor for rat embryos not only in the culture medium composed of rabbit serum but also in rat serum, the usual culture medium supporting the normal embryonic growth as well as in the uterus.

\section{Embryotrophic activity of methylamine-C3 and C3b}

Involvement of the internal thiolester bond of C3 in the embryotrophic activity was examined to investigate the mechanisms of this activity since this bond is known as the critical functional site of C3 in the complement system (Law and Dodds, 1997). The

Fig. 2. C3 and growth of rat embryos in the culture medium composed of rat serum. (A) Consumption of culture medium constituents by rat embryos cultured in rat serum. Three, six or nine embryos were cultured from day 9.5 for $48 \mathrm{~h}$ in a bottle containing $4 \mathrm{ml}$ of rat serum. Plots of total embryonic protein versus concentration of culture medium constituents at the end of culture are shown. Each data point represents an individual bottle. Equations of the estimated regression line and correlation coefficients for each constituent are shown. Asterisks indicate statistical significance (***, $P<0.001)$. (B) Embryonic protein of rat embryos cultured from day 9.5 for $48 \mathrm{~h}$ in C3depleted rat serum. CVF $(0.5 \mu \mathrm{g} / 10 \mu \mathrm{l} / \mathrm{bottle})$ and C3 $(0.25$ $\mathrm{mg} / \mathrm{ml}$ ) were added to the culture medium composed of rat serum 30 min before culture. Means of six embryos are shown. Error bars represent s.e.m. Values with the same letter are not significantly different $(P<0.05)$. (C) Appearance of rat embryos cultured in C3-depleted rat serum. $c p$, chorio-allantoic placenta; em, embryo proper; vy, visceral yolk sac. (D) Electrophoretic analysis of the culture medium composed of rat serum after the culture. The culture media $(150 \mathrm{nl} / 15 \mu l)$ were applied on each lane and their proteins were stained with $C B B$. internal thiolester bond of purified rat C3 was inactivated by its methylamine treatment (methylamine-C3), which can be confirmed by loss of its hemolytic activity (Law etal., 1980). Hemolytic activity of methylamine-C3 was about $4 \%$ compared to that of C3 (Fig. 3A). The addition of methylamine-C3 to the culture medium composed of rabbit serum, however, increased embryonic protein to the same extent as the addition of C3 (Fig. 3A), indicating that the internal thiolester bond of $\mathrm{C} 3$ was not involved in the embryotrophic activity.

Embryotrophic activity of $\mathrm{C} 3 \mathrm{~b}$, known as the primary active fragment of C3 in the complement system (Law and Reid, 1995), was also examined by the culture of rat embryos in the culture medium composed of rabbit serum to investigate the mechanisms of this activity. C3b prepared with activated CVF had the $\alpha$ '-chain smaller than the $\alpha$-chain by the $M$ of $C 3 a$, about 10,000 , as shown by electrophoretic analysis (Fig. 3B). The addition of C3b to the culture medium did not increase the embryonic protein but decreased it (Fig. 3C). The morphological growth of the embryos was also inhibited by the addition of C3b (Fig. 3D). Western blot

\section{A}
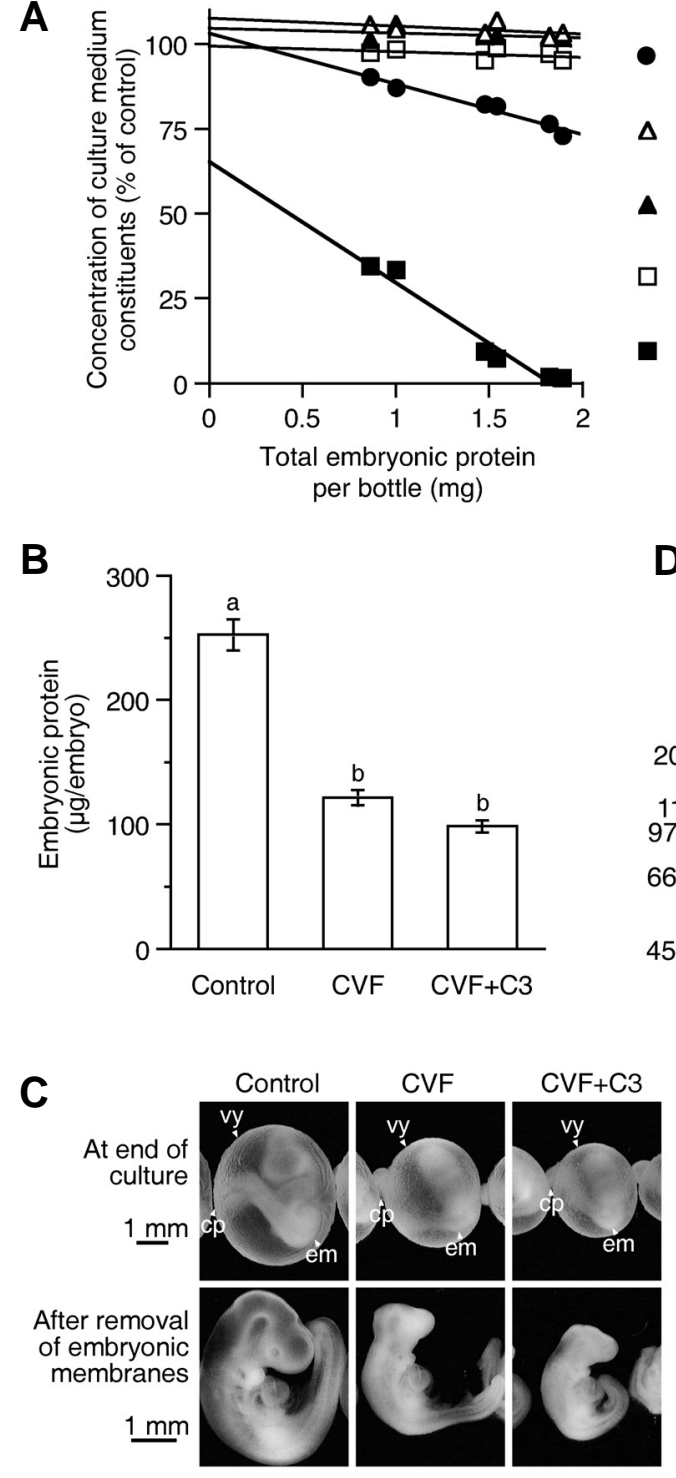

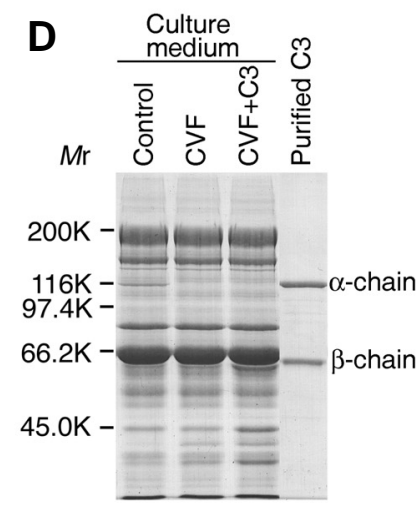

- C3 (control: $2.06 \mathrm{mg} / \mathrm{ml})$ $y=-14.9 x+103.1 \quad r=0.978^{* *}$

$\Delta$ Total protein (control: $50.0 \mathrm{mg} / \mathrm{ml}$ ) $y=-2.31 x+107.5 r=0.529$

$\Delta$ Albumin (control: $36.8 \mathrm{mg} / \mathrm{ml}$ ) $y=-1.36 x+104.5 \quad r=0.341$

$\square$ Transferrin (control: $4.65 \mathrm{mg} / \mathrm{ml}$ ) $y=-1.64 x+99.4 \quad r=0.459$

- Glucose (control: $2.38 \mathrm{mg} / \mathrm{ml}$ ) $y=-35.4 x+65.4 \quad r=0.979^{\star * \star}$ 
analysis of the culture media after the culture showed no $\alpha^{\prime}$-chain in the culture medium added with $\mathrm{C} 3 \mathrm{~b}$, indicating the degradation of C3b during the culture (Fig. 3E). The trace amount of CVF in the C3b, if any, is considered not enough to affect the embryonic growth either directly or indirectly, since it loses C3-cleaving activity during the preparation of $\mathrm{C} 3$ for the culture experiment and its amount is much less than that of C3b. Similarly, the addition of
C3a prepared with activated CVF did not increase the embryonic protein (data not shown). From these results it is suggested that C3b has no embryotrophic activity.

\section{Embryotrophic activity of rabbit C3 for rat embryos}

Purified rabbit C3 was added to the culture medium composed of rabbit serum to examine its embryotrophic activity for rat em-
A

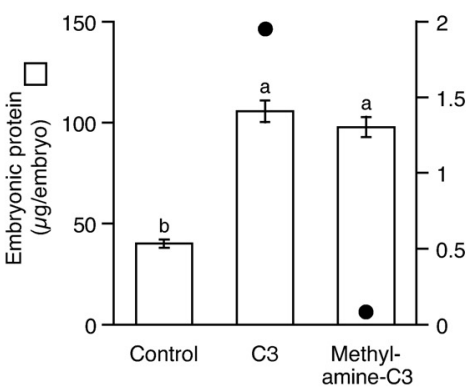

C

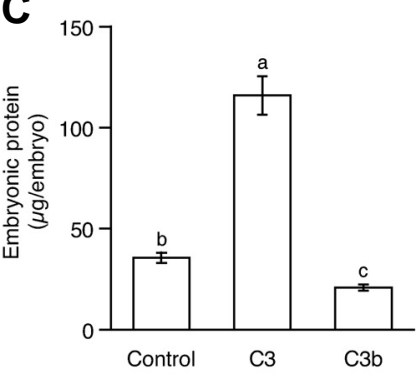

B

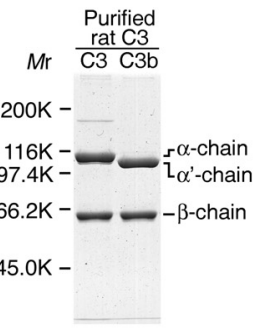

E

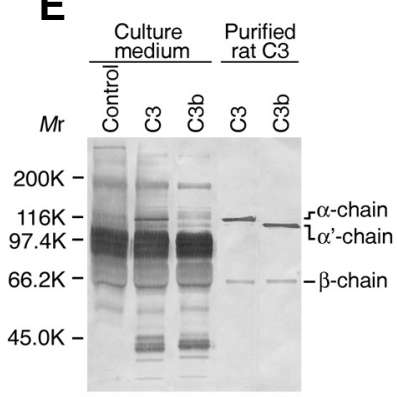

A

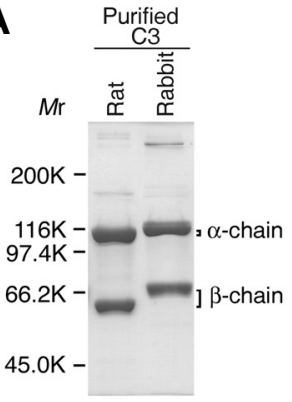

C

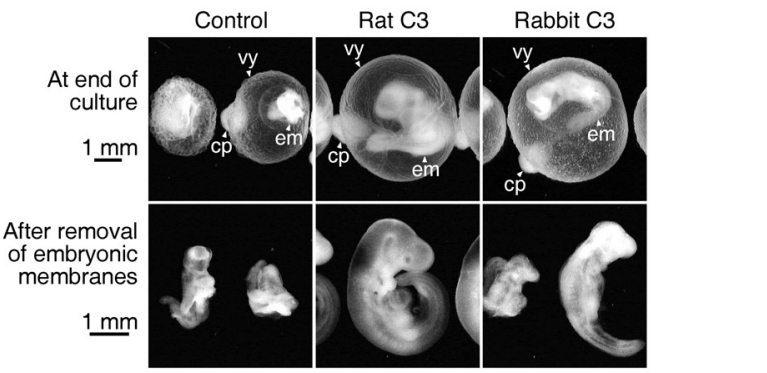

D

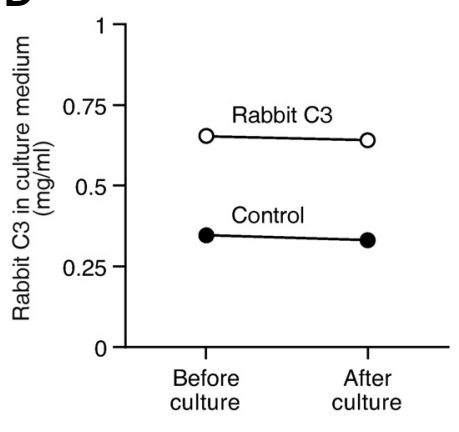

B
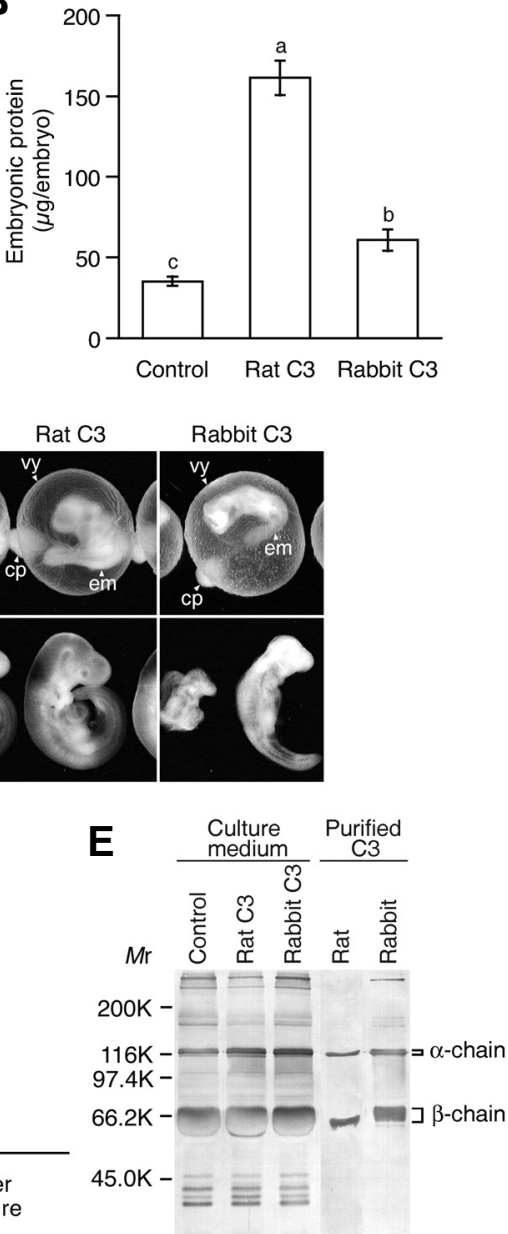

Fig. 3 (Left). Embryotrophic activity of methylamine-C3 and C3b. (A) Embryonic protein of rat embryos cultured from day 9.5 for 48 h in rabbit serum with the addition of C3 or methylamine-C3 $(0.30 \mathrm{mg} / \mathrm{ml})$. Means of six embryos are shown. Error bars represent s.e.m. Values with the same letter are not significantly different $(P<0.05)$. (B) Electrophoretic analysis of C3b prepared with activated CVF. C3 or C3b $(2 \mu \mathrm{g} / 10 \mu \mathrm{l})$ were applied on each lane and stained with CBB. (C) Embryonic protein of rat embryos cultured from day 9.5 for $48 \mathrm{~h}$ in rabbit serum with the addition of C3 $10.41 \mathrm{mg} /$ $\mathrm{ml}$ ) or C3b $(0.46 \mathrm{mg} / \mathrm{ml})$. Means of six embryos are shown. Error bars represent s.e.m. Values with the same letter are not significantly different $(P<0.05)$. (D) Appearance of rat embryos cultured in rabbit serum with the addition of C3 or C3b. cp, chorio-allantoic placenta; em, embryo proper; vy, visceral yolk sac. (E) Western blot analysis of the culture media composed of rabbit serum after the culture with the addition of C3 or C3b. The culture media (100 $\mathrm{nl} / 5 \mu \mathrm{l})$ were applied on each lane and their C3s were detected with rabbit anti-rat C3 lgG. C3 and C3b samples were diluted at the same ratio as in the culture media. Extra broad bands are due to rabbit lgG reacted with the secondary antibody.

Fig. 4 (Right). Embryotrophic activity of rabbit C3 for rat embryos. (A) Electrophoretic analysis of purified rabbit C3. Purified C3s (2.5 $\mu$ g/10 $\mu$ ) were applied on each lane and stained with CBB. (B) Embryonic protein of rat embryos cultured from day 9.5 for $48 \mathrm{~h}$ in rabbit serum with the addition of rat or rabbit C3 $(0.31 \mathrm{mg} / \mathrm{m} /)$. Means of six embryos are shown. Error bars represent s.e. $\mathrm{m}$. Values with the same letter are not significantly different $(P<0.05)$. (C) Appearance of rat embryos cultured in rabbit serum with the addition of rat or rabbit C3. cp, chorio-allantoic placenta; em, embryo proper; vy, visceral yolk sac. (D) Concentrations of rabbit C3 in the culture medium composed of rabbit serum before and after the culture with or with out the addition of rabbit C3. The concentrations were determined by SRID. Means of two bottles are shown. (E) Western blot analysis of the culture media after the culture. The culture media $(250 \mathrm{nl} / 5 \mu \mathrm{l})$ were applied on each lane and their C3s were detected with goat anti-rabbit C3 lgG. Rat and rabbit C3 samples were diluted at the same ratio as in the culture media. 
bryos. This is because the concentration of $\mathrm{C} 3$ in rabbit serum $(0.43$ $\mathrm{mg} / \mathrm{ml})$ is only about one-fifth of that in rat serum $(2.06 \mathrm{mg} / \mathrm{ml})$ and might be quantitatively insufficient for the growth of rat embryos cultured in rabbit serum. Rabbit C3 purified from rabbit plasma had somewhat larger molecular weights than rat C3 for both $\alpha$ - and $\beta$ chains as shown by electrophoretic analysis (Fig. 4A). The addition of rabbit $\mathrm{C} 3$ to the culture medium increased embryonic protein of cultured rat embryos by only one-fifth of the increase by the same amount of rat C3 (Fig. 4B). The morphological growth of the embryos was also poor with the addition of rabbit C3 (Fig. 4C).

Because the degradation of rabbit $\mathrm{C} 3$ might be the cause of its weak embryotrophic activity for rat embryos, the amount of rabbit C3 in the culture medium were determined by SRID and Western blot analysis. With the addition of purified rabbit $\mathrm{C} 3$, the concentration of rabbit $\mathrm{C} 3$ in the culture medium became as twice as that of the control group, and almost the same before and even after the culture (Fig. 4D). With the addition of rabbit C3, more amounts of the $\alpha$ - and $\beta$-chains of rabbit C3 were detected in the culture medium after the culture (Fig. 4E), supporting that significant degradation of rabbit $\mathrm{C} 3$ did not occur during the culture. From these results, rabbit $\mathrm{C} 3$ is considered to have only weak embryotrophic activity for rat embryos.

\section{Detection of $\mathrm{C} 3$ in rat embryos}

The presence and distribution of C3 in day 9.5 or 10.5 rat pregnant uteri corresponding to the cultured embryos were examined to investigate the embryotrophic activity of C3 in utero. Immunohistochemistry of $\mathrm{C} 3$ in the rat pregnant uteri using anti-rat C3 Ig G showed the presence of C3 that is considered to be derived from maternal blood sinus in the decidual tissue (Fig. 5). In day 9.5 embryos, C3 was detected on the visceral yolk sac but not on the embryo proper although the embryo proper faces maternal C3 in the yolk cavity the same as the visceral yolk sac does (Fig. 5, left panels). In day 10.5 embryos, C3 was detected on the visceral yolk sac but not on the embryo proper, which was enveloped in the visceral yolk sac (Fig. 5, right panels).

The presence and distribution of C3 was further examined in vitroin rat embryos explanted at day 9.5 or 10.5 (Fig. 6A) by confocal microscopy using FITC-anti C3 lgG. In day 9.5 embryos, C3 was detected as fluorescence on the visceral yolk sac but not on the embryo proper as in the immunohistochemistry in the pregnant uteri (Fig. 6B, upper left panel), which was obvious when confocal images were captured by aligning the focal plane to the surface of the visceral yolk sac (Fig. 6B, lower left panel). In day 10.5 embryos, C3 was detected on the visceral yolk sac, while the embryo proper enveloped by the visceral yolk sac could not be seen (Fig. 6B, right panels). The fluorescence of FITCanti C3 IgG was disappeared by the addition of C3 that neutralized anti-C3 IgG, indicating the specificity of this method (data not shown). It is considered from these results that $\mathrm{C} 3$ can function as an embryotrophic factor through the visceral yolk sac both in utero and in vitro.

\section{Binding of $\mathrm{C} 3$ to rat embryos}

The binding of C3 to rat embryos explanted at day 9.5 or 10.5 corresponding to the cultured embryos was examined by confocal microscopy using FITC-C3. In both day 9.5 and 10.5 embryos, fluorescence was observed only on the visceral yolk sac (Fig. 6C, upper panels) and disappeared by the addition of rat $\mathrm{C} 3$ as a competitor, indicating the specific binding of $\mathrm{C} 3$ to the visceral yolk sac. This fluorescence was weak, probably because the $\mathrm{C} 3$ binding sites was already occupied by maternal C3 in the uterus, which could not be removed by preincubation of the embryos in rabbit serum or in HBSS (data not shown). By the addition of methylamine-C3 or rabbit C3 as competitors, the fluorescence also disappeared showing the binding of these unfragmented C3s to the visceral yolk sac (data not shown). However, the fluorescence remained, although weakened, on the visceral yolk sac when C3b was added as a competitor (Fig. 6C, lower panels). These results indicate that the unfragmented C3s bound to the visceral yolk sac stronger than $\mathrm{C} 3 \mathrm{~b}$, which is compatible with the embryotrophic activity of the C3s and C3b in the present experiments.

\section{Discussion}

The present results indicate that C3 functions as an embryotrophic factor in early postimplantation rat embryos probably through the visceral yolk sac. Uninvolvement of the internal thiolester bond of $\mathrm{C} 3$ in the embryotrophic activity indicates mechanisms different from those for activation of the complement system, because the covalent binding by this bond is critical for the activities of $\mathrm{C} 3$ as a component of the complement system in both classical and alternative pathways (Law and Dodds, 1997). This is supported by the present findings that the unfragmented C3s, including methylamine-C3, bound to the visceral yolk sac as the possible action site stronger than $\mathrm{C} 3 \mathrm{~b}$, which binds to known specific receptors as the primary active fragment of $\mathrm{C} 3$ in the

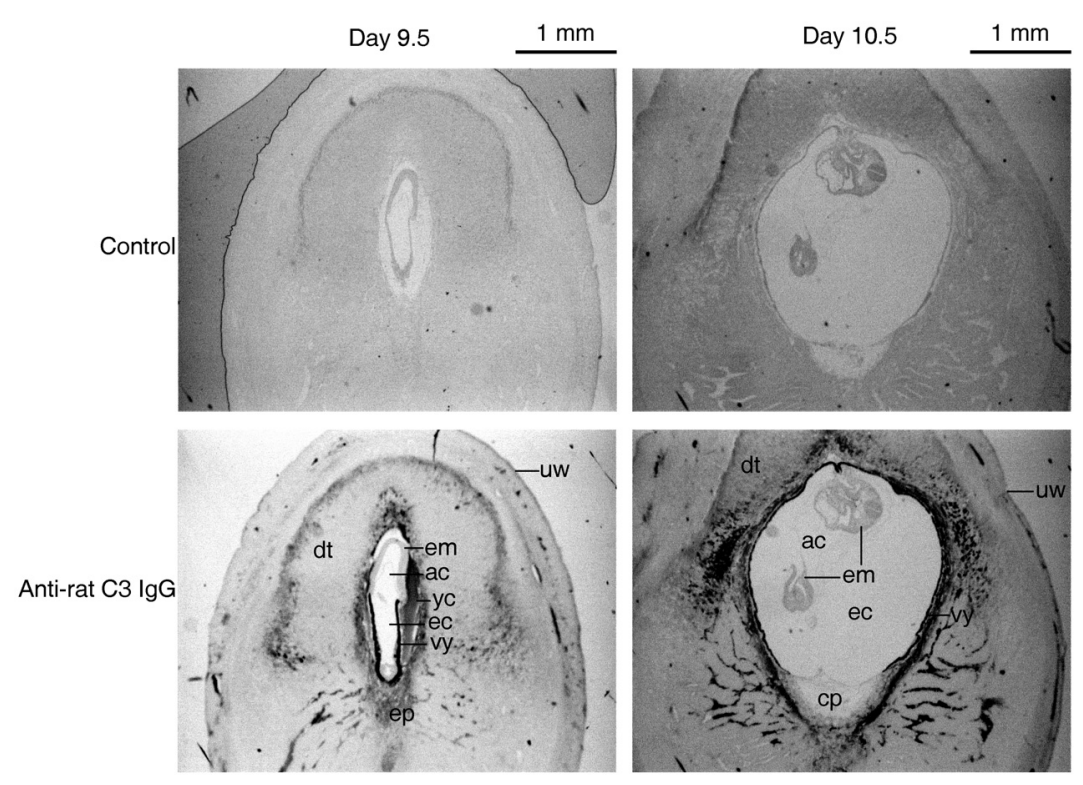

Fig. 5. Detection of C3 in rat pregnant uteri. Transverse sections of day 9.5 or 10.5 rat pregnant uteri were immunostained with anti-rat C3 $\mathrm{lg} G$. The dark area indicates the presence of $C 3$. The mesometrium side is at the bottom. ac, amniotic cavity; $c p$, chorioallantoic placenta; $d t$, decidual tissue; ec, exocoelomic cavity; em, embryo proper; ep, ectoplacental cone; uw, uterine wall; yc, yolk sac cavity; vy, visceral yolk sac. 
complement system (Law and Reid, 1995).

The mechanisms of the embryotrophic activity of C3 are not known at present. The binding of $\mathrm{C} 3$ together with its selective consumption in the culture medium suggests the involvement of some receptor for $\mathrm{C} 3$ on the visceral yolk sac. In this context, it is noteworthy that LR8, a chicken lipoprotein receptor, binds and transport C3 from the yolk to the oocyte in the egg (Recheis et al., 2005). This is because megalin (LRP-2/GP330), a mammalian close relative of $L R 8$ and a multiligand endocytic receptor belonging to the low-density-lipoprotein receptor (LDLR) family, is expressed on the visceral yolk sac in accordance with the binding of C3 in the present study (Drake et al., 2004). Although known ligands for megalin includes albumin and transferrin but not $\mathrm{C} 3$ at present (Christensen and Birn, 2002), megalin or some LDLR relative might be involved in the embryotrophic activity of C3. After

A

Bright-field photo

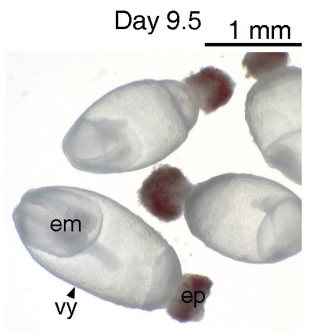

B

FITC-anti C3 IgG
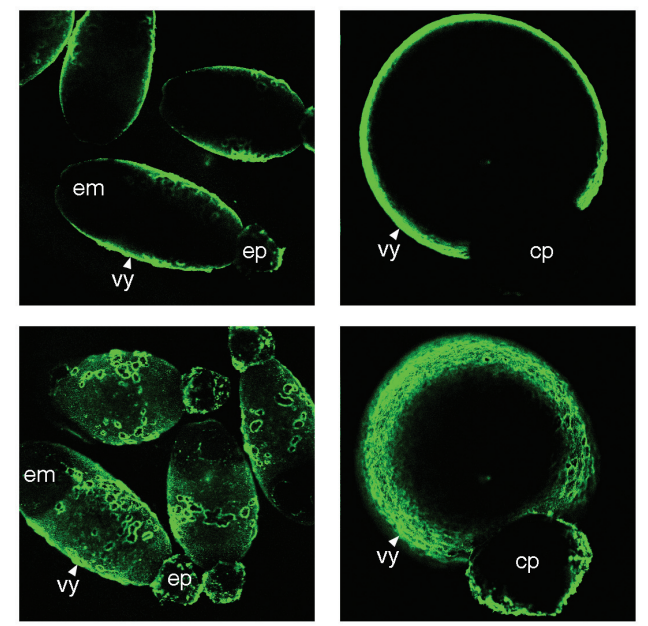

C

FITC-anti C3 IgG with focal plane aligned to surface of visceral yolk sac

C
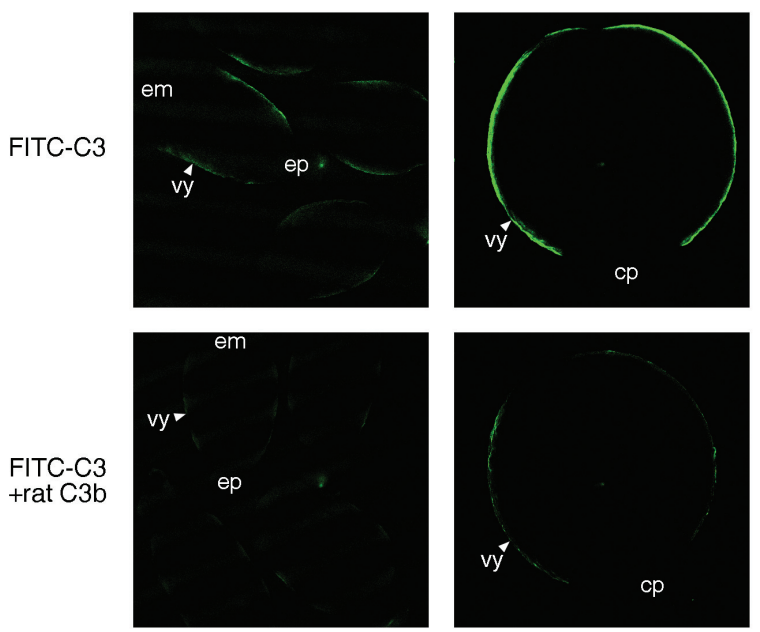

the binding to the visceral yolk sac, C3 seems to be degraded and not to be recycled, since many $\mathrm{C} 3$ fragments, but not unfragmented $\mathrm{C} 3$, are detected in the visceral yolk sac by proteome analysis (Usami et al., 2007).

The function of C3 as an embryotrophic factor in postimplantation rat embryos is a surprise because the complement system in the culture medium has been considered detrimental to the embryos. It has been shown that heat-inactivation of the complement system at $56^{\circ} \mathrm{C}$ for $30 \mathrm{~min}$ in rat serum as a culture medium improves the growth of cultured rat embryos (New etal., 1976). Seemingly this is inconsistent with the embryotrophic activity of C3. However, the complement components heatinactivated under these conditions do not include $\mathrm{C} 3$, but $\mathrm{C} 1 \mathrm{q}$ and factor B (Law and Reid, 1995) that consume C3 on complement activation. Furthermore, the degradation products of $\mathrm{C} 3$ may inhibit embryonic growth as observed with the addition of C3b in the present study. The improved embryonic growth by the heatinactivation may be due to the protection of C3 from its consumption by the activated complement system.

There seems species specificity in the embryotrophic activity of C3 because rabbit C3 was less effective for rat embryos in spite of its phylogenetically close relationship to rat C3 (Lambris et al., 1994) and rabbit embryos can be cultured well in rabbit serum (Ninomiya et al., 1993). Uninvolvement of the internal thiolester bond, the region most conserved across species (Lambris et al., 1994), in the embryotrophic activity of C3 is consistent with this species specificity. It is expected that comparisons of primary structures of C3 among various species would reveal the functional site of C3 as an embryotrophic factor. This is because some heterologous C3s, such as human and bovine C3, seem effective for cultured rat embryos, supporting their growth satisfactory (Chatot et al., 1980; Klug et al., 1990). In mammals, the complete primary structures of C3 are available for rats (Misumi et al., 1990), mice (Lundwall et al., 1984; Wetsel et al., 1984), humans (De Bruijn and Fey, 1985) and guinea pigs (Auerbach et al., 1990) at present. Unfortunately, only partial primary structures of C3 are available for rabbits (Kusano et al., 1986).

There may be stage specificity in the embryotrophic activity of C3. This is because rat embryos at later developmental stages could grow in synthetic culture media without the addition of C3. Day 14 rat embryos were successfully cultured for $26 \mathrm{~h}$ in a chemically defined culture medium of Earle's balanced salt solution and $0.7 \%$ bovine serum albumin (Barber et al., 1993). On the other hand, a culture method for day 11.5 rat embryo with Dulbecco's minimal essential medium/Ham's F12 supplemented with $20 \%$ fetal bovine serum was not applicable to day 10.5 rat

Fig. 6. Detection and binding of $\mathrm{C} 3$ in rat embryos explanted at day 9.5 or 10.5. (A) Bright field photos of explanted rat embryos. (B) Detection of C3 on rat embryos. Embryos were incubated with FITC-anti C3 $\operatorname{lgG}(25 \mu \mathrm{g} / \mathrm{ml})$ and the fluorescence was observed by confocal microscopy. The binding specificity was confirmed by disappearance of the fluorescence with the addition of rat $C 3(2.5 \mathrm{mg} / \mathrm{m} /)$. (C) Binding of C3 to rat embryos. Ratembryos were incubated with FITC-C3 $(25 \mu \mathrm{g} / \mathrm{ml})$, and the fluorescence was observed by confocal microscopy. Binding of rat C3, methylamine-C3, rabbit $C 3$ and rat C3b was examined by their addition as competitors at a 100-fold higher concentration $(2.5 \mathrm{mg} / \mathrm{ml})$. The bright area indicates the fluorescence by FITC-anti C3 Ig G or FITC-C3. $c p$, chorio-allantoic placenta; em, embryo proper; ep, ectoplacental cone; vy, visceral yolk sac. 
embryos (Ornoy et al., 2003).

The present findings strengthen the role of $\mathrm{C} 3$ in a broad range of the reproductive process, from fertilization to embryonic growth, in vertebrates although the site and mechanisms of its action seem different. It has been shown that $\mathrm{C} 3 \mathrm{~b}$ bound to membrane cofactor protein (MCP), or C3-like factor bound to complement receptors $\mathrm{CR} 1$ and $\mathrm{CR} 3$ is involved in the fertilization of humans and frogs (Anderson et al., 1993; Cervoni et al., 1992; Llanos et al., 2000). Phagocytic activity in mouse placental trophoblasts is enhanced by C3b probably through CR1 (Albieri et al., 1999; Amarante-Paffaro etal., 2004). Furthermore, embryotrophic function of iC3b, the cleaved product of $\mathrm{C} 3 \mathrm{~b}$, in mouse blastocysts probably through the rodent complement receptor-related protein y (Crry) and CR3 has been reported (Lee et al., 2004).

On the contrary to the embryotrophic activity of $\mathrm{C} 3$, no reproductive failures have been shown in C3-deficient individuals, such as those of humans, guinea pigs, dogs, rabbits and mice (BitterSuermann and Burger, 1989; Wessels et al., 1995), other than mild impairment of pregnancy including higher resorption rate, in C3-knockout mice (Chow et al., 2009). Probably, this means that some trophic and/or anatomical factor can functionally compensate for C3 as an embryotrophic factor in uterounder C3-deficient conditions. Such functional compensation might involve the increase of the C3-related proteins, such as $\alpha 2$-macroglobulin (Campbell et al., 1986), during pregnancy. $\alpha 2$-Macroglobulin, which is depleted in the culture medium by rat embryos (Priscott et al., 1983), is markedly increased in maternal blood (Panrucker et al., 1983) and synthesized in the uterine decidua (Gu et al., 1995 ) in rats. In mice, endometrial $\alpha 2$-macroglobulin is suggested to regulate the blastocyst development (Sayegh et al., 1997).

The embryotrophic activity of $\mathrm{C} 3$ seems to be one explanation for the significance of $\mathrm{C} 3$ synthesized locally in the uterus. It has been indicated that $\mathrm{C} 3$, mostly synthesized in the liver, is also synthesized in the uterine endometrium of various species including rats (Sundstrom et al., 1989) and humans (Sayegh et al., 1996), which is stimulated by estradiol or chorionic gonadotropin and inhibited by progesterone (Brown et al., 1990; Sherwin et al., 2007). It is suggested from the present findings that uterine $C 3$ functions as an embryotrophic factor at earlier embryonic stages when the maternal blood sinus is not yet formed. This notion is supported by the growth promoting activity of other locally synthesized C3, such as observed for blastocyst and osteoclast development in mice (Lee et al., 2004; Sato et al., 1993), B lymphocyte proliferation in mice (Cahen-Kramer et al., 1994), neural plate formation in frogs (McLin et al., 2008) and limb regeneration in urodeles (Rio-Tsonis et al., 1998).

In conclusion, the present study has revealed new functions of C3 as an embryotrophic factor and of the visceral yolk sac as its possible action site in early postimplantation growth of rat embryos. Further study will lead to deeper understanding of the regulation mechanisms of postimplantation embryonic growth in mammals.

\section{Materials and Methods}

\section{Embryo culture}

Postimplantation embryos explanted from Wistar rats (Crlj: WI, Charles River Laboratories Japan, Kanagawa, Japan) at day 9.5 of gestation (plug day = day 0.5 ) were cultured for $48 \mathrm{~h}$ by the roller bottle method (Usami and Ohno, 1996). Three embryos and $4 \mathrm{ml}$ of a culture medium were placed in a $30-\mathrm{ml}$ culture bottle. Rabbit and rat sera used as culture media were prepared by immediate centrifugation after blood collection, and were heat-inactivated at $56^{\circ} \mathrm{C}$ for $30 \mathrm{~min}$ (Morriss-Kay, 1993). For determination of embryotrophic activity, the culture medium was composed of $3 \mathrm{ml}$ of rabbit or rat sera and $1 \mathrm{ml}$ of C3s or C3b. C3s, C3b, CVF and dialyzed rat serum were dialyzed against Hanks' balanced salt solution (HBSS) before the addition to the culture medium. In the control groups, the same amount of HBSS was added to the culture medium. After the culture, embryonic protein content, freed from embryonic membranes, was determined as an index of embryonic growth (Usami and Ohno, 1996). Statistical significance of differences in embryonic protein among the groups was examined by one-way analysis of variance and the Tukey method after log transformation.

\section{Electrophoresis and N-terminal sequence analysis}

Sodium dodecyl sulfate-polyacrylamide gel electrophoresis (SDSPAGE) was performed using $7.5 \%$ T mini gels (Laemmli, 1970). Samples were incubated with sample buffer containing 2-mercaptoethanol as a reducing agent at $37^{\circ} \mathrm{C}$ for $1 \mathrm{~h}$, and were loaded onto the gel. After electrophoresis, the gel was stained with Coomassie Brilliant Blue R-250 (CBB) using Quick-CBB (Wako Pure Chemical, Osaka, Japan) or was subjected to electroblotting.

$\mathrm{N}$-terminal amino acid sequences of proteins were determined by microsequencing (Matsudaira, 1987). Samples were separated by SDSPAGE and electroblotted to a polyvinylidene difluoride (PVDF) membrane (Trans-Blot $0.2 \mu \mathrm{m}$, Bio-Rad, Hercules, CA). Tank blotting was performed with CAPS buffer (10 mM 3-(cyclohexylamino)-1-propane sulfonic acid (CAPS), pH 11, 10\% (v/v) methanol) and a transfer cell (Mini Trans-Blot Cell, Bio-Rad) at a constant current at $0.5 \mathrm{~A}$ for $30 \mathrm{~min}$. The proteins on the PVDF membrane stained with CBB were cut out and applied to a protein sequencer (PPSQ-10, Shimadzu, Kyoto, Japan). The obtained $\mathrm{N}$-terminal amino acid sequences were searched against the Swiss-Prot database to identify the proteins.

\section{Preparation of C3s, cobra venom factor, C3b and anti-C3 IgGs}

Rat and rabbit C3s were purified from EDTA plasma by a fast protein liquid chromatography method (Guiguet et al., 1987) with some modifications (Usami and Ohno, 2005). Methylamine-treated rat C3 (methylamine-C3) was prepared by incubation of purified rat C3 with $100 \mathrm{mM}$ methylamine in $0.01 \mathrm{M}$ phosphate buffered saline (PBS, pH 7.5) at $37^{\circ} \mathrm{C}$ for $2 \mathrm{~h}$. Hemolytic activity of $\mathrm{C} 3$ was determined as $\mathrm{CH} 50$ units (Kolb et al., 1979) using C3-deficient human serum (Sigma). CVF was purified from lyophilized cobra venom (Naja naja kausia, Wako Pure Chemical), and rat $\mathrm{C} 3 \mathrm{~b}$ was prepared by cleavage of purified rat $\mathrm{C} 3$ with activated CVF (Usami and Ohno, 2005). Rabbit anti-rat C3 IgG was purified from rabbit antiserum obtained by immunization of Japanese White rabbits (Std: JW/CSK, Japan SLC, Shizuoka, Japan) with rat C3 using the MAbTrap GII (GE Healthcare). Rabbit anti-rat C3 IgG was further purified by affinity chromatography with a column (HiTrap NHS-activated HP, $1 \mathrm{ml}$, GE Healthcare) coupled with rat C3. Goat anti-rabbit C3 Ig G was purified in the same manner from goat anti-rabbit C3 antiserum (Cappel, Irvine, $\mathrm{CA}$ ) using a column coupled with rabbit $\mathrm{C} 3$ instead of rat $\mathrm{C} 3$.

\section{Western blot analysis}

Samples were separated by SDS-PAGE and electroblotted to a nitrocellulose membrane (Trans-Blot $0.45 \mu \mathrm{m}$, Bio-Rad). Semi-dry blotting was performed with continuous transfer buffer ( $48 \mathrm{mM}$ Tris, $39 \mathrm{mM}$ glycine, $1.3 \mathrm{mM} \mathrm{SDS}, 20 \%$ methanol) and a transfer cell (Trans-Blot SD Cell, Bio-Rad) at a constant voltage at $15 \mathrm{~V}$ with a current limit at $0.41 \mathrm{~A}$ membrane for $30 \mathrm{~min}$. The membrane was stained with rabbit anti-rat $\mathrm{C} 3$ IgG and the Immunoblotting ABC-POD (R) Kit (Wako Pure Chemical), or with goat anti-rabbit $\mathrm{C} 3 \mathrm{IgG}$ and the same kit in which the biotin- 
conjugated goat anti-rabbit lgG antibody was replaced by biotin-conjugated rabbit anti-goat IgG antibody (Jackson ImmunoResearch, West Grove, PA).

\section{Determination of culture medium constituents}

$\mathrm{C} 3 \mathrm{~s}$, albumin and transferrin concentrations in rat serum were determined by single radial immunodiffusion (SRID) (Catty and Raykundalia, 1988). For the SRID of C3s and transferrin, rabbit anti-rat C3 antibody, goat anti-rabbit C3 antibody or rabbit anti-rat transferrin antibody (Cappel) with purified rat $\mathrm{C} 3$, purified rabbit $\mathrm{C} 3$ or rat transferrin (Cappel) as a standard, respectively, was used. For the SRID of albumin, the Bind A Rid for rat albumin 'NL' (Binding Site, Birmingham, UK) was used. Total protein concentration was determined by the Bradford method using the Protein Assay (Bio-Rad) and bovine serum albumin (Wako Pure Chemical) as a standard. Glucose concentration was determined by the glucose oxidase method using the Glucose B-Test Wako (Wako Pure Chemical). Each determination was made in triplicate.

\section{Immunohistochemistry}

Pregnant rat uteri at day 9.5 or 10.5 of gestation were cut into pieces as short as the embryo widths. The uterine pieces containing the embryos were fixed in Bouin's fluid, and their paraffin sections $8 \mu \mathrm{m}$ thick were made. The sections were stained immunohistochemically with rabbit antirat C3 IgG and the Pathostain ABC-POD (R) Kit (Wako Pure Chemical). Normal rabbit IgG was used for control staining. Diamino benzidine was used for color development, and no counter staining was made.

\section{Confocal microscopy}

Fluorescein-labeled rabbit anti-rat C3 IgG (FITC-anti C3 IgG) and rat C3 (FITC-C3) were prepared by incubation of rabbit anti-rat C3 IgG or rat $\mathrm{C} 3$ in $0.25 \mathrm{M} \mathrm{NaHCO}_{3}(\mathrm{pH} 9.0)$ mixed with fluorescein-4-isothiocyanate (FITC, Wako Pure Chemical) in dimethylsulfoxide $(10 \mathrm{mg} / \mathrm{ml})$ at a ratio of $50 \mu \mathrm{g}$ FITC per mg protein for 2 or $3 \mathrm{~h}$ at room temperature. The incubation mixture was applied on a gel filtration column ( $5 \mathrm{ml}$, Sephadex G-10, GE Healthcare) and eluted with PBS ( $\mathrm{pH} 7.4)$ for the separation of the labeled molecule from free FITC. The eluted FITC-anti C3 IgG and FITC-C3, of which the F/P ratio ranged from 3.82 to 5.32 , were dialyzed against PBS.

Rat embryos were explanted at day 9.5 or 10.5 of gestation, and were preincubated in rat serum for $30 \mathrm{~min}$ so that they would lose adhesiveness to containers and recover from damage due to the explantation procedures. After the preincubation, the embryos were washed six times with ice-cold HBSS containing $0.1 \% \mathrm{NaN}_{3}$ (csHBSS), and were incubated with FITC-anti C3 lgG or FITC-C3 $(25 \mu \mathrm{g} / \mathrm{ml})$ in csHBSS containing $1 \%$ bovine serum albumin in the presence or absence of rat $\mathrm{C} 3$, methylamine-C3, rabbit $\mathrm{C} 3$ or rat $\mathrm{C} 3 \mathrm{~b}(2.5 \mathrm{mg} / \mathrm{ml})$ for $30 \mathrm{~min}$ on ice. After the incubation, the embryos were washed six times with csHBSS, and observed for fluorescence with a laser scanning confocal microscope (Radiance 2000, BioRad) and control software (LaserSharp 2000, Bio-Rad) at excitation Ar $488 \mathrm{~nm}$, iris 12, $166 \mathrm{lps}$, Kalman mode, channel green and $4 \times$ magnification with an UPlan Apochromat objective. Gain and offset were adjusted to quench autofluorescence of the control embryo. Much care was taken to obtain images within a few scans because of rapid decay of the fluorescence.

\section{Acknowledgements}

This work was partly supported by the ministry of education, science, sports and culture, grant-in-aid for exploratory research, 15658090, 2003-2005.

\section{References}

ALBIERI, A., KIPNIS, T. and BEVILACQUA, E. (1999). A possible role for activated complement component 3 in phagocytic activity exhibited by the mouse trophoblast. Am J Reprod Immuno/41: 343-352.
AMARANTE-PAFFARO, A., QUEIROZ, G.S., CORRE, S.T., SPIRA, B. and BEVILACQUA, E. (2004). Phagocytosis as a potential mechanism for microbial defense of mouse placental trophoblast cells. Reproduction 128: 207-218.

ANDERSON, D.J., ABBOTT, A.F. and JACK, R.M. (1993). The role of complement C3b and its receptors in sperm-oocyte interaction. Proc Nat/ Acad Sci USA 90 10051-10055.

AUERBACH, H.S., BURGER, R., DODDS, A. and COLTEN, H.R. (1990). Molecular basis of complement $\mathrm{C} 3$ deficiency in guinea pigs. J Clin Invest 86: 96-106.

BARBER, C.V., CARDA, M.B. and FANTEL, A.G. (1993). A new technique for culturing rat embryos between gestation days 14 and 15. Toxicol /n vitro 7: 695700.

BITTER-SUERMANN, D. and BURGER, R. (1989). C3 deficiencies. Curr Top MicroBiol Immuno/ 153: 223-233.

BROWN, E.O., SUNDSTROM, S.A., KOMM, B.S., YI, Z., TEUSCHER, C. and LYTTLE, C.R. (1990). Progesterone regulation of estradiol-induced rat uterine secretory protein, complement C3. Biol Reprod 42: 713-719.

CAHEN-KRAMER, Y., MÅTENSSON, I.-L. and MELCHERS, F. (1994). The structure of an alternate form of complement C3 that displays costimulatory growth factor activity for B lymphocytes. J Exp Med 180: 2079-2088.

CAMPBELL, R.D., CARROLL, M.C. and PORTER, R.R. (1986). The molecular genetics of components of complement. Adv Immuno/38: 203-244.

CATTY, D. and RAYKUNDALIA, C. (1988). Gel immunodiffusion, immunoelectrophoresis and immunostaining methods. In Antibodies(Ed. D. Catty). IRL Press, Oxford, pp. 137-167.

CERVONI, F., OGLESBY, T.J., ADAMS, E.M., MILESI-FLUET, C., NICKELLS, M. FENICHEL, P., ATOKINSON, J.P. and HSI, B.-L. (1992). Identification and characterization of membrane cofactor protein of human spermatozoa. $J$ Immuno/148: 1431-1437.

CHATOT, C.L., KLEIN, N.W., PIATEK, J. and PIERRO, L.J. (1980). Successful culture of rat embryos on human serum: use in the detection of teratogens. Science 207: 1471-1473.

CHOW, W.N., LEE, Y.L., WONG, P.C., CHUNG, M.K., LEE, K.F. and YEUNG, W.S (2009). Complement 3 deficiency impairs early pregnancy in mice. Mol Reprod Dev76: 647-655.

CHRISTENSEN, E.I. and BIRN, H. (2002). Megalin and cubilin: multifunctional endocytic receptors. Nat Rev Mol Cel/ Bio/3: 256-266.

COCKROFT, D.L. (1979). Nutrient requirements of rat embryos undergoing organogenesis in vitro. $J$ Reprod Fert 57: 505-510.

DAHA, M.R., STUFFERS-HEIMAN, M., KIJLSTRA, A. and VANES, L.A. (1979) Isolation and characterization of the third component of rat complement. Immunology 36: 63-70.

DE BRUIJN, M.H.L. and FEY, G.H. (1985). Human complement component C3: cDNA coding sequence and derived primary structure. Proc Nat/ Acad Sci USA 82: 708-712.

DRAKE, C.J., FLEMING, P.A., LARUE, A.C., BARTH, J.L., CHINTALAPUDI, M.R. and ARGRAVES, W.S. (2004). Differential distribution of cubilin and megalin expression in the mouse embryo. AnatRec A Discov Mol Cel/EvolBio/277: 163170.

FLYNN, T.J., FRIEDMAN, L., BLACK, T.N. and KLEIN, N.W. (1987). Methionine and iron as growth factors for rat embryos cultured in canine serum. J Exp Zool 244: 319-324.

GLANZER, G.W., GRESSENS, P., LEE, S.J., GIBNEY, G., GOZES, Y. BRENNEMAN, D.E. and HILL, J.M. (1999). Activity-dependent neurotrophic factor: a potent regulator of embryonic growth and development. Anat Embryol 200: 65-71.

GRESSENS, P., HILL, J.M., GOZES, I., FRIDKIN, M. and BRENNEMAN, D.E. (1993). Growth factor function of vasoactive intestinal peptide in whole cultured mouse embryos. Nature 362: 155-158.

GU, Y., SRIVASTAVA, R.K., OU, J., KRETT, N.L., MAYO, K.E. and GIBORI, G. (1995). Cell-specific expression of activin and its two binding proteins in the rat decidua: role of $\alpha_{2}$-macroglobulin and follistatin. Endocrinology 136: 38153822.

GUIGUET, M., DETHIEUX, M.-C., EXILIE-FRIGÉE, M.-F., BIDAN, Y., LAUTISSIER, J.-L. and MACK, G. (1987). Third component of rat complement. Purification from plasma and radioimmunoassay in culture media from cell lines. J Immun 
Methods 96: 157-164.

HUXHAM, I.M. and BECK, F. (1985). Maternal transferrin uptake by and transfer across the visceral yolk sac of the early postimplantation rat conceptus in vitro. Dev Biol110: 75-83.

KARABULUT, A.K., LAYFIELD, R. and PRATTEN, M.K. (1999). The mechanism of growth-promoting effects of prolactin in embryogenesis - Links to growth factors. Cells Tissues Organs 164: 2-13.

KLUG, S., LEWANDOWSKI, C., WILDI, L. and NEUBERT, D. (1990). Bovine serum: an alternative to rat serum as a culture medium for the rat whole embryo culture. Toxicol In vitro 4: 598-601.

KOLB, W.P., KOLB, L.M. and PODACK, E.R. (1979). C1q: isolation from human serum in high yield by affinity chromatography and development of a highly sensitive hemolytic assay. J Immuno/122: 2103-2111.

KUSANO, M., CHOI, N.-H., TOMITA, M., YAMAMOTO, K., MIGITA, S., SEKIYA, T. and NISHIMURA, S. (1986). Nucleotide sequence of cDNA and derived amino acid sequence of rabbit complement C3 $\alpha$-chain. Immunol Invest 15: 365-378.

LAEMMLI, U.K. (1970). Cleavage of structural proteins during the assembly of the head of bacteriophage T4. Nature 227: 680-685

LAMBRIS, J.D., MAVROIDIS, M. and SUNYER, J.O. (1994). Phylogeny of third component of complement, C3. In New Aspects of Complement Structure and Function(Ed. A. Erdei). R.G. Landes Company, Georgetown, Texas, pp. 15-34.

LAW, S.K., LICHTENBERG, N.A. and LEVINE, R.P. (1980). Covalent binding and hemolytic activity of complement proteins. Proc Natl Acad Sci USA 77: 71947198.

LAW, S.K.A. and DODDS, A.W. (1997). The internal thioester and the covalent binding properties of the complement proteins C3 and C4. Protein Sci6: 263274.

LAW, S.K.A. AND REID, K.B.M. (1995). Complement. IRL Press, Oxford.

LEE, Y.-L., LEE, K.-F., XU, J.-S., HE, Q.-Y., CHIU, J.-F., LEE, W.M., LUK, J.M. and YEUNG, W.S.B. (2004). The embryotrophic activity of oviductal cell-derived complement $\mathrm{C} 3 \mathrm{~b}$ and $\mathrm{iC} 3 \mathrm{~b}$, a novel function of complement protein in reproduction. J Biol Chem 279: 12763-12768.

LLANOS, R.J., WHITACRE, C.M. and MICELI, D.C. (2000). Potential involvement of C3 complement factor in amphibian fertilization. Comp Biochem Physiol $A$ Mol Integr Physiol 127: 29-38.

LUNDWALL, Å., WETSEL, R.A., DOMDEY, H., TACK, B.F. and FEY, G.H. (1984). Structure of murine complement component C3. I. Nucleotide sequence of cloned complementary and genomic DNA coding for the $\beta$ chain. $\mathrm{J} B \mathrm{BiO} / \mathrm{Chem}$ 259: $13851-13856$

MATSUDAIRA, P. (1987). Sequence from picomole quantities of proteins electroblotted onto polyvinylidene difluoride membranes. J Biol Chem 262: 10035-10038.

McLIN, V.A., HU, C.-H., SHAH, R. and JAMRICH, M. (2008). Expression of complement components coincides with early patterning and organogenesis in Xenopus laevis. Int J Dev Bio/52: 1123-1133.

MISUMI, Y., SOHDA, M. and IKEHARA, Y. (1990). Nucleotide and deduced amino acid sequence of rat complement C3. Nucleic Acids Res 18: 2178.

MORRISS-KAY, G.M. (1993). Postimplantation mammalian embryos. In Essential Developmental Biology (Eds. C.D. Stern and P.W.H. Holland). IRL Press, Oxford, pp. 55-66.

NEW, D.A.T., COPPOLA, P.T. and COCKROFT, D.L. (1976). Improved development of head-fold rat embryos in culture resulting from low oxygen and modifications of the culture serum. J Reprod Fert 48: 219-222.

NINOMIYA, H., KISHIDA, K., OHNO, Y., TSURUMI, K. and ETO, K. (1993). Effects of trypan blue on rat and rabbit embryos cultured in vitro. Toxicol In vitro 7: 707717.

ORNOY, A., YACOBI, S. and YAFFEE, P. (2003). A simple method of culture of 11.5-day-old rat embryos in DMEM/F12 and 20\% fetal bovine serum. J Anat 203: 419-423.

PANRUCKER, D.E., LAI, P.C.W. and LORSCHEIDER, F.L. (1983). Distribution of acute-phase $\alpha$-macroglobulin in rat fetomaternal compartments. Am J Physiol 245: E138-142

PRATTEN, M.K. (1998). The role of exogenous growth-promoting factors and their receptors in embryogenesis. Reprod Toxico/12: 201-207.
PRICE, R.L., HALEY, S.T., BULLARD, T.A., GOLDSMITH, E.G., SIMPSON, D.G., THIELEN, T.E., YOST, M.J. and TERRACIO, L. (2003). Effects of plateletderived growth factor-AA and -BB on embryonic cardiac development. Anat Rec Part $A$ 272A: $424-433$

PRISCOTT, P.K., GOUGH, P.G. and BARNES, R.D. (1983). Serum protein depletion by cultured post-implantation rat embryos. Experientia 39: 1042-1043.

RECHEIS, B., RUMPLER, H., SCHNEIDER, W.J. and NIMPF, J. (2005). Receptormediated transport and deposition of complement component $\mathrm{C} 3$ into developing chicken oocytes. Cell Mol Life Sci62: 1871-1880.

RIO-TSONIS, K.D., TSONIS, P.A., ZARKADIS, I.K., TSAGAS, A.G. and LAMBRIS, J.D. (1998). Expression of the third component of complement, C3, in regenerating limb blastema cells of urodeles. J Immuno/161: 6819-6824.

SATO, T., ABE, E., JIN, C.H., HONG, M.H., KATAGIRI, T., KINOSHITA, T. AMIZUKA, N., OZAWA, H. and SUDA, T. (1993). The biological roles of the third component of complement in osteroclast formation. Endocrinology 133: 387 404.

SAYEGH, R.A., TAO, X.J., AWWAD, J.T. and ISAACSON, K.B. (1996). Localization of the expression of complement component 3 in the human endometrium by in situ hybridization. J Clin Endocrinol Metab 81: 1641-1649.

SAYEGH, R.A., TAO, X.J., LEYKIN, L. and ISAACSON, K.B. (1997). Endotherial $\alpha-$ macroglobulin; localization by in situhybridazation and effect on mouse embryo development in vitro. J Clin Endocrnol Metab 82: 4189-4195.

SHERWIN, J.R., SHARKEY, A.M., CAMEO, P., MAVROGIANIS, P.M., CATALANO, R.D., EDASSERY, S. and FAZLEABAS, A.T. (2007). Identification of nove genes regulated by chorionic gonadotropin in baboon endometrium during the window of implantation. Endocrinology 148: 618-626.

SUNDSTROM, S.A., KOMM, B.S., PONCE-DE-LEON, H., YI, Z., TEUSCHER, C. and LYTTES, C.R. (1989). Estrogen regulation of tissue-specific expression of complement C3. J Biol Chem 264: 16941-16947.

TANIMURA, T. and SHEPARD, T.H. (1970). Glucose metabolism by rat embryos in vitro. Proc Soc EXp Biol Med 135: 51-54.

TRAVERS, J.P., EXELL, L., HUANG, B., TOWN, E., LAMMIMAN, M.J., PRATTEN, M.K. and BECK, F. (1992). Insulin and insulinlike growth factors in embryonic development - Effects of a biologically inert insulin (guinea pig) on rat embryonic growth and development in vitro. Diabetes 41 : 318-324

ULGER, H., KARABULUT, A.K. and PRATTEN, M.K. (2000). The growth promoting effects of bFGF, PD-ECGF and VEGF on cultured postimplantation rat embryos deprived of serum fractions. J Anat 2000: 207-219.

USAMI, M., MITSUNAGA, K. and NAKAZAWA, K. (2007). Comparative proteome analysis of the embryo proper and yolk sac membrane of day 11.5 cultured rat embryos. Birth Defects Res B Dev Reprod Toxico/80: 383-395.

USAMI, M., NAKAURA, S., KAWASHIMA, K., TANAKA, S. and TAKANAKA, A. (1992). Culture of postimplantation rat embryos in rabbit serum for the identification of the growth factor in fractionated rat serum. J Exp Zoo/264: 214-218.

USAMI, M. and OHNO, Y. (1996). Partial purification and characterization of serum embryotrophic factor required for early postimplantation growth of rat embryos in culture. J Exp Zoo/276: 403-414.

USAMI, M. and OHNO, Y. (2005). Preparation of complement fragments C3b and C3a from purified rat complement component $\mathrm{C} 3$ by activated cobra venom factor. J Pharmacol Toxicol Methods 52: 260-263.

WESSELS, M.R., BUTKO, P., MA, M., WARREN, H.B., LAGE, A.L. and CARROLL, M.C. (1995). Studies of group B streptococcal infection in mice deficient in complement component $\mathrm{C} 3$ or $\mathrm{C} 4$ demonstrate an essential role for complement in both innate and acquired immunity. Proc Nat/ Acad Sci USA 92: 11490 11494

WETSEL, R.A., LUNDWALL, Å., DAVIDSON, F., GIBSON, T., TACK, B.F. and FEY, G.H. (1984). Structure of murine complement component C3. II. Nucleotide sequence of cloned complementary DNA coding for the $\alpha$ chain. $J$ Biol Chem 259: 13857-13862.

WILLIAMS, C., PRISCOTT, P.K., OLIVER, I.T. and YEOH, G.C.T. (1986). Albumin and transferrin synthesis in whole rat embryo cultures. J Embryol Exp Morphol 92: 33-41.

YOUNG, S., LEMM, A.R., BECKMAN, D.A., BRENT, R.L. and LLOYD, J.B. (1997) Uptake and processing of ${ }^{59} \mathrm{Fe}$-labelled and ${ }^{125}$-labelled rat transferrin by early organogenesis rat conceptuses in vitro. Placenta 18: 553-562. 


\section{Further Related Reading, published previously in the Int. J. Dev. Biol.}

See our recent Special Issue Placenta edited by Joan S. Hunt and Kent L. Thornburg at: http://www.ijdb.ehu.es/web/contents.php?vol=54\&issue=2-3

Development and function of trophoblast giant cells in the rodent placenta

Dong $\mathrm{Hu}$ and James C. Cross

Int. J. Dev. Biol. (2010) 54: 341-354

Contemporary comparative placenta research - an interview with Allen Enders

Kent L. Thornburg and Joan S. Hunt

Int. J. Dev. Biol. (2010) 54: 231-236

From Chemical Embryology to Nucleosome Patterning - an interview with Roumen G. Tsanev

Stefan Nonchev and Irina Tsaneva

Int. J. Dev. Biol. (2009) 53: 383-391

Expression of complement components coincides with early patterning and organogenesis in Xenopus laevis Valérie A. McLin, Cheng-Hui Hu, Rina Shah and Milan Jamrich

Int. J. Dev. Biol. (2008) 52: 1123-1133

Reassessing the role of protein-carbohydrate complementarity during sperm-egg interactions in the mouse

Barry D. Shur

Int. J. Dev. Biol. (2008) 52: 703-715

Spatiotemporal expression of the selenoprotein $\mathbf{P}$ genein postimplantational mouse embryos

Se-Ra Lee, Jung-Min Yon, In-Jeoung Baek, Mi-Ra Kim, Chun-Gui Park, Beom-Jun Lee, Young-Won Yun and Sang-Yoon Nam

Int. J. Dev. Biol. (2008) 52: 1005-1011

Identical triplets and twins developed from isolated blastomeres of 8- and 16-cell mouse embryos supported with tetraploid blastomeres

Andrzej K. Tarkowski, Waclaw Ozdzenski and Renata Czolowska

Int. J. Dev. Biol. (2005) 49: 825-832

Multilineage hematopoietic progenitor activity generated autonomously in the mouse yolk sac: analysis using angiogenesisdefective embryos.

Christine Rampon and Philippe Huber

Int. J. Dev. Biol. (2003) 47: 273-280

Expression patterns of follistatin and two follistatin-related proteins during mouse development. E De Groot, A Feijen, D Eib, A Zwijsen, H Sugino, G Martens and A J Van Den Eijnden-Van Raaij Int. J. Dev. Biol. (2000) 44: 327-330
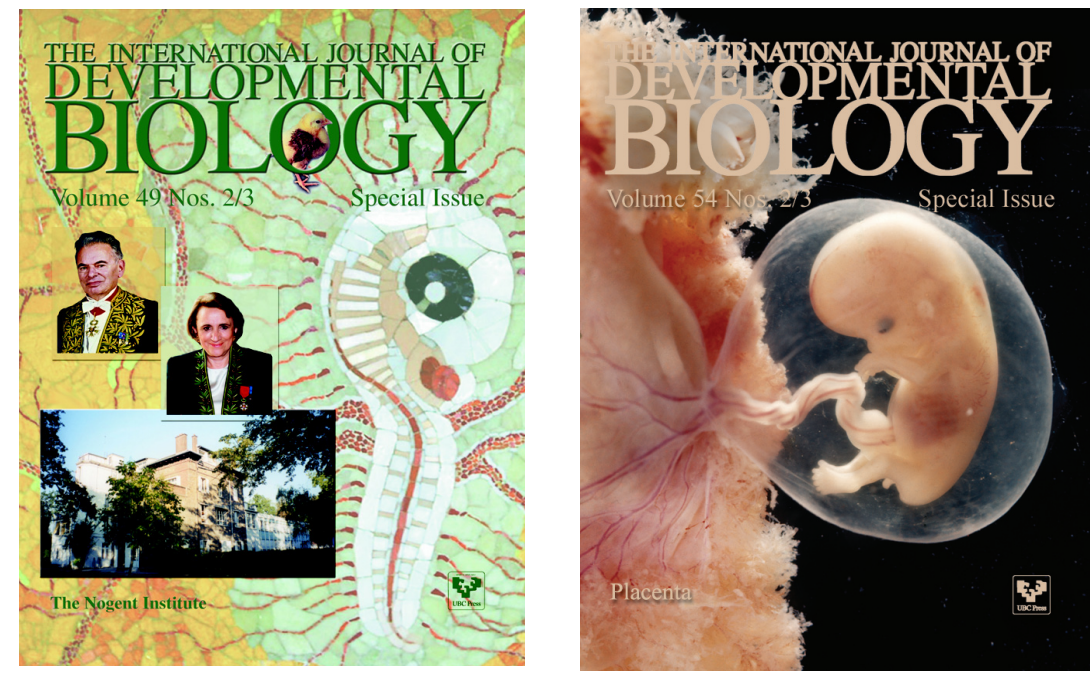

5 yr ISI Impact Factor $(2009)=3.253$
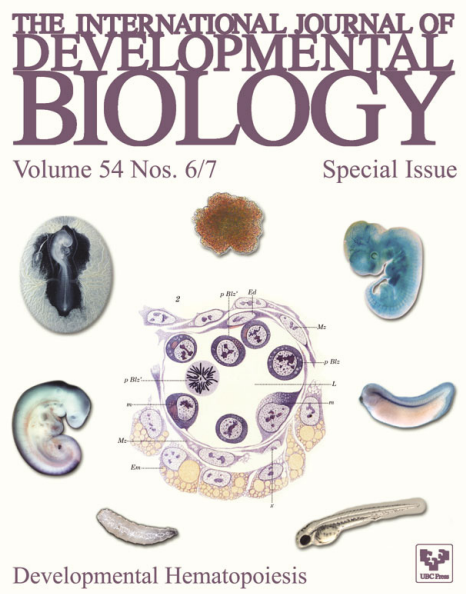